Article

\title{
Impact of Forest Logging Ban on the Welfare of Local Communities in Northeast China
}

\author{
Yude Geng ${ }^{1}$, Siboyu Sun ${ }^{1}\left(\mathbb{D}\right.$ and Youn Yeo-Chang ${ }^{2, *} \mathbb{C}$ \\ 1 School of Economics and Management, Northeast Forestry University, Harbin 150040, China; \\ gydnefu@126.com (Y.G.); sunsiboyu@foxmail.com (S.S.) \\ 2 Department of Agriculture, Forestry and Bioresource Sciences and Research Institute of Agriculture \& Life \\ Science, Seoul National University, Seoul 08826, Korea \\ * Correspondence: youn@snu.ac.kr; Tel.: +82-2-880-4754
}

check for

updates

Citation: Geng, Y.; Sun, S.; Yeo-Chang, Y. Impact of Forest Logging Ban on the Welfare of Local Communities in Northeast China.

Forests 2021, 12, 3 .

https: / /dx.doi.org/10.3390/f12010003

Received: 24 October 2020

Accepted: 18 December 2020

Published: 22 December 2020

Publisher's Note: MDPI stays neutral with regard to jurisdictional claims in published maps and institutional affiliations.

Copyright: () 2020 by the authors. Licensee MDPI, Basel, Switzerland. This article is an open access article distributed under the terms and conditions of the Creative Commons Attribution (CC BY) license (https: / / creativecommons.org/ licenses/by/4.0/).

\begin{abstract}
Background and Objectives: In order to effectively protect and restore natural forest resources, the Chinese government banned logging in state-owned forests of northeast China in April 2015. This is an enormous change for people who live in that region, especially forestry workers and their families, who depend on state-owned forestry enterprises. Following the welfare changes in worker households in a timely manner is conducive to gaining a better understanding of the development status of state-owned forest areas, so as to provide a scientific basis for the government to formulate forest policies that will contribute to sustainable development. Materials and Methods: Using Sen's theory of welfare measurement, we measured the change in welfare of forestry worker households based on an empirical research framework that measures the function and gap in welfare before and after the logging ban. Results: (1) The welfare of worker households changed due to the logging ban in terms of function; social security, dwelling conditions, and psychological conditions improved, whereas economic status and social opportunity declined. (2) The logging ban had different impacts on the welfare of forestry worker households depending on their livelihood. Low-income households solely dependent on forestry work or engaged in this work for diversified income were impacted most by the ban, while high-income households engaged in forestry as a major source of income or for complementary income were impacted less. (3) The logging ban seems to affect social welfare distribution: the proportion of households classified as low welfare increased, while that of high-welfare households decreased.
\end{abstract}

Keywords: state-owned forest area; household welfare; fuzzy evaluation method; Theil index

\section{Introduction}

Forests provide many benefits for the population, such as carbon storage, timber harvesting, and conservation of water and biodiversity [1]. However, these benefits often conflict [2]. Forests make a huge contribution to the economy, while deforestation and forest degradation are serious threats to sustainable development. Forest management policies should reasonably balance these contradictions to achieve sustainable development and forest protection [3,4]. In April 2015, the Chinese government introduced the policy of a comprehensive commercial logging ban (CCLB) in all natural forests in state-owned forest areas of northeast China [5]. The northeast state-owned forest area was the largest timber production base in China. By 2015, it had provided nearly 1.1 billion cubic meters of commercial timber, accounting for nearly half of the national commercial timber output during that period. Due to timber harvesting, the exploitable forest resources had run out and the forest ecosystem was seriously damaged [6,7]. Following massive floods in in the Yangtze River Basin in 1998, the Chinese government appreciated the significance of forest ecosystems and implemented a series of forest protection policies, especially to protect the upper watershed, and launched the Natural Forest Protection Program (NFPP) in 1999 to protect forest ecosystems in the upper watersheds [8]. Since that time, timber production 
took a back seat [9]. In 2015, stricter measures for the protection of natural forests were launched. Logging was prohibited in all natural forests in northeast China [10].

The logging ban mainly affects two groups: forest industry enterprises and local residents. Specifically, forest industry enterprises need to change their main goal from logging to reforestation. This means companies have lost their main business (timber harvesting) and now mainly depend on state financial subsidies such as afforestation, forest tending, forest administration, and protection. Local residents face job transfer and even unemployment. A stricter forest protection system was implemented, forbidding production of any form of wood. In northeast China, most non-timber forest products (NTFPs) are plantations of black fungi mushrooms, which are dependent on wood. The logging ban causes a lack of raw materials, which directly leads to increased costs. Forests play important roles in local communities [11]. Residents have been actively exploring other means of making a living to adapt to the logging ban [12-14]. Therefore, timely discussion of the changes in local residents' welfare is conducive to understanding the effects of policy implementation and its impact on people's lives, so as to help in the implementation of follow-up policies, and then solve the livelihood problems of state-owned forest areas and promote the development of society.

The study area includes the DaXing'an, XiaoXing'an, and Changbai Mountains of northeast China (Figure 1). Altogether, the forest area is about 38.75 million hectares, accounting for $24 \%$ of the nation's total [15]. Our research takes the worker households of Longjiang, Jilin, and Inner Mongolia Daxinganling forestry enterprises, with the Daxinganling group as an example, and introduces Sen's function and capability welfare theory to analyze the changes in the welfare of worker households in northeast state-owned forest areas before and after the logging ban by using data from two surveys conducted in 2012 and 2017.
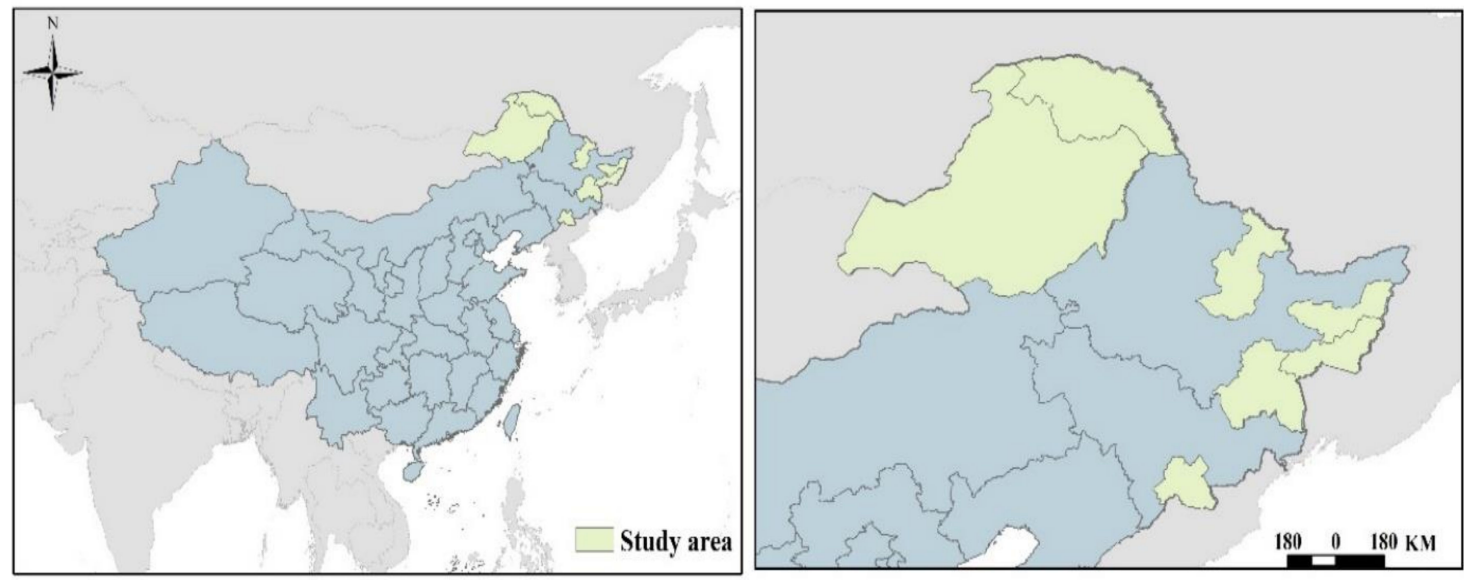

Figure 1. Study area.

\section{Theory and Research Framework}

\subsection{Theory}

Before conducting the study, it is important to clarify the definition of welfare. Traditional welfare theory has two varieties, objectivist, and subjectivist. Objectivist welfare theory defines welfare from the perspectives of actual consumer expenditure, the goods and services individuals possess and the per capita gross domestic product (GDP) [16], basic items required by every rational person [17]. Subjectivist welfare considers welfare as a reflection of individual or collective preferences; the utility is obtained by consuming certain goods or services, and data is used in models of subjective well-being [18]. However, the utility of different individuals cannot be compared and directly measured [19]. More generally, traditional welfare theory separates objective and subjective welfare. However, welfare is both objective, such as income, goods, and services, and subjective, such as utility 
and satisfaction. Welfare is a vague and complicated concept. In addition, traditional welfare theory lacks the measurement to obtain the potential capability of welfare [20].

Thus, Amartya Sen posited a function and capability welfare theory, proposing a capability approach to evaluate welfare in multiple dimensions [21-23] and address the gaps in traditional welfare theory. The core idea of this theory is to use the "capability of individuals to realize valuable activities" to evaluate welfare [24]. Welfare is considered a functional collection that measures the level by evaluating a range of functions [25]. This not only considers present welfare status but also potential status and possible future welfare. Sen examined six functional indicators: income level, living conditions, health condition, education and knowledge, social interactions, and psychological condition. These indicators are expressed through five instrumental freedoms: political freedom, economic conditions, social opportunities, guaranteed transparency, and protection. However, Sen's five instrumental freedoms and six functional indicators are not the full content of capability. By researching, we can find many kinds of valuable functional indicators, and some of these instrumental freedoms are not listed in Sen's theory [26]. Sen's capability approach only provides a general analysis framework for welfare issues. In our research, we need to determine different indicators based on our own research objectives and background, focusing especially on particular variables. Sen's welfare theory is developmental and dynamic. However, it is based on the welfare of individuals, making it difficult to perceive welfare gaps in collectives [27]. When we focus on the improvement of welfare levels, we also need to pay attention to fairness and impartiality in collectives to prevent social problems caused by the wide welfare gap.

\subsection{Research Framework}

Given these shortfalls, we attempted to construct a welfare capability research framework that combines welfare function and the welfare gap in a model in which the function is used to evaluate efficiency and the gap is used to evaluate fairness. We define welfare function as a series of functional indicators including a subjective index (satisfaction) and objective indicators (economic status, dwelling condition, etc.) to comprehensively measure the welfare level of worker households. We defined the welfare gap as the gap in welfare levels between worker households.

\section{Method and Data}

\subsection{Method}

\subsubsection{Method of Calculating Welfare Function}

Welfare is an ambiguous and relatively broad concept. It is difficult to define and describe accurately. In addition, when assessing the welfare of worker households, some of the selected indicators, such as wage income and medical insurance, are objective and others, such as life satisfaction and confidence in the future, are subjective and potentially ambiguous. How can we put subjective and objective indices together for a comprehensive evaluation? The fuzzy mathematics method provides a way of thinking about dealing with such problems [28]. It can put different kinds of indicators together and then provide numerical values that can be directly compared. This method has also been widely used in equity research, welfare research, and poverty measurement in recent years $[20,26]$. Therefore, this paper chooses fuzzy mathematics to evaluate the changes in welfare. The task consists of the following steps:

First, set a fuzzy function of welfare. Welfare is expressed as fuzzy set $X$, including economic status, social security, dwelling condition, social opportunity, and psychological condition. The five items constitute a subset $w$ of $X$.

$$
w^{n}=\left\{X, \mu_{w}(x)\right\}
$$

In this equation, $w^{n}$ equals the fuzzy function of the $n$th worker household's welfare, where $X$ is the fuzzy set of the worker household's welfare. $X \in X, \mu_{w}(x)$ represents the 
membership degree of $x$ to $w \cdot \mu_{w}(x) \in[0,1]$, and when $\mu_{w}(x)=1$ the welfare is the best, when $\mu_{w}(x)=0$ it is the worst, and when $\mu_{w}(x)=0.5$ it is fuzzy [29].

Second, set the membership degree function, which depends on the type of variables [30].

Dichotomous variables (D):

$$
\mu\left(x_{i j}\right)= \begin{cases}0 & x=0 \\ 1 & x=1\end{cases}
$$

Continuous variables $(C)$ and virtual qualitative variables $(\mathrm{Q})$ :

$$
\begin{gathered}
\mu\left(x_{i j}\right)= \begin{cases}0 & 0 \leq x_{i j} \leq x_{i j}^{\min } \\
\frac{x_{i j}-x_{i j}^{\text {min }}}{x_{i j}^{\max }-x_{i j}^{\text {min }}} & x_{i j}^{\min }<x_{i j}<x_{i j}^{\max } \\
1 & x_{i j} \geq x_{i j}^{\max }\end{cases} \\
\mu\left(x_{i j}\right)= \begin{cases}0 & 0 \leq x_{i j} \leq x_{i j}^{\min } \\
\frac{x_{i j}^{\max }-x_{i j}}{x_{i j}^{\max }-x_{i j}^{\text {min }}} & x_{i j}^{\min }<x_{i j}<x_{i j}^{\max } \\
1 & x_{i j} \geq x_{i j}^{\max }\end{cases}
\end{gathered}
$$

where $i$ represents the function, $j$ represents the index, and $x_{i j}$ represents sub-index $j$ of function $i$, and $x_{i j}{ }^{m i n}$ represents the minimum value and $x_{i j}{ }^{m a x}$ the maximum value of $x_{i j}$. When there is a positive correlation between the index value and the welfare function, we use Formula (3). When there is a negative correlation between the index value and the welfare function, we use Formula (4).

Third, determine the weight of each variable.

$$
\omega_{i j}=\ln \left[\frac{1}{\overline{\mu\left(x_{i j}\right)}}\right]
$$

$\overline{\mu\left(x_{i j}\right)}=\frac{1}{n} \sum_{p=1}^{n} \mu\left(x_{i j}\right)^{p}$, where $\overline{\mu\left(x_{i j}\right)}$ denotes the mean of sub-index $j$ of function $i$ for the surveyed sample.

Finally, add up with weights to calculate the welfare function:

$$
f\left(x_{i}\right)=\sum_{j=1}^{k} \bar{\mu}\left(x_{i j}\right) \times \omega_{i j} / \sum_{j=1}^{k} \omega_{i j}
$$

A membership degree equal to 1 indicates that welfare is in good condition, 0 indicates poor condition, and 0.5 indicates that the welfare status is in a fuzzy state, neither better nor worse. We define a membership degree less than 0.4 as low welfare, between 0.4 and 0.6 as medium welfare, and greater than 0.6 as high welfare $[25,31]$.

\subsubsection{Method of Calculating Welfare Gap}

The Theil index is primarily used to measure income disparity. Income is closely related to welfare [20]. In this study, we replaced income with welfare and calculated the Theil index of welfare to evaluate disparities in welfare before and after the logging ban, defined as the welfare gap. With the logging ban, the livelihood types of worker families in state-owned forest areas have been differentiated [13]. Compared with other methods, the Theil index not only can calculate the overall difference, but also can be decomposed into inter-group and within-group differences [32-34] Therefore, the Theil index can help us to more accurately reflect the welfare gap and the gaps between different livelihood 
types, introduced into the welfare gap study. The Theil index ranges between 0 and $\infty$, with 0 representing an equal distribution and higher values representing a larger welfare gap.

$$
\begin{gathered}
T p=\sum_{i}\left(\frac{Y_{i}}{Y}\right) T p_{i}+\sum_{i}\left(\frac{Y_{i}}{Y}\right) \ln \left(\frac{\frac{Y_{i}}{Y}}{\frac{N_{i}}{N}}\right)=\sum_{i}\left(\frac{Y_{i}}{Y}\right) T p_{i}+T b r=T w r+T b r \\
T p_{i}=\sum_{i}\left(\frac{Y_{i j}}{Y_{i}}\right) \ln \left(\frac{\frac{Y_{i j}}{Y_{i}}}{\frac{N_{i j}}{N_{i}}}\right) \\
\text { Contribution rate }=\frac{T w r}{T p}+\frac{T b r}{T p}=1
\end{gathered}
$$

where $T p$ indicates welfare gap, and is the sum of within-group gap (Twr) plus betweengroup gap (Tbr); $T p_{i}$ is the $i$ th group in the Theil index; $Y_{i}$ is the sum welfare function of livelihood type $i$; $Y$ is the sum welfare function of all types; $Y_{i j}$ is worker households' welfare function $j$ in livelihood type $i ; N_{i}$ is the total number of samples for each livelihood type $i ; N$ is the total number of samples; and $N_{i j}$ is the $j$ th number of type $i$.

\subsubsection{Classification of Worker Households}

According to scholars' classification of livelihood strategies [13,35,36], we divide the workers' households in northeast state-owned forest areas into four types based on the annual forestry net income and the proportion of forestry net income accounts among total income. As of 2012, the average annual income of forestry worker households was 25,960.00 $\mathrm{RMB}$, and in 2017 it was 44,364.10 RMB. The average proportion of forestry income was $79.3 \%$ in 2012 and $78.4 \%$ in 2017. The groups were classified as follows: Group 1: forestry as the main job: income from forestry is high, and this group is highly dependent on forestry. Group 2: forestry as a complementary source of income: income from forestry is also high, but this group is not entirely dependent on forestry. Group 3: households solely dependent on forestry: income from forestry is low, but their livelihood depends on it. Group 4: households engaged in forestry for diversified livelihood: they have diversified income streams.

\subsection{Data}

\subsubsection{Variable Descriptions}

Following Sen's theory of welfare function and capability (Sen 1991, 1999), we define welfare function by the following aspects: economic status, social security, dwelling

\begin{tabular}{|c|c|c|c|c|}
\hline $\begin{array}{c}\text { Dimensions of } \\
\text { Welfare Function }\end{array}$ & Index & $\begin{array}{l}\text { Type of } \\
\text { Variable }\end{array}$ & $\begin{array}{c}\text { Index Assignment and } \\
\text { Meaning }\end{array}$ & Literature \\
\hline \multirow{5}{*}{ Economic status } & Wage income & $\mathrm{C}$ & $\begin{array}{l}\text { Wage income of family } \\
\text { members }\end{array}$ & \multirow{5}{*}{$\begin{array}{l}\text { Economic status is recognized as one of the most } \\
\text { important factors influencing welfare }[20,26,37] \text {, } \\
\text { including income and consumption. Expanded } \\
\text { income comes from increased government } \\
\text { expenditure, mainly including retirement pay } \\
\text { and subsidies, in order to reduce the income } \\
\text { distribution gap. }\end{array}$} \\
\hline & $\begin{array}{l}\text { Non-timber forest } \\
\text { product (NTFP) } \\
\text { business income }\end{array}$ & $\mathrm{C}$ & $\begin{array}{l}\text { Non-timber forest } \\
\text { products income }\end{array}$ & \\
\hline & Property income & C & Property income & \\
\hline & Expanded income & $\mathrm{C}$ & Expanded income & \\
\hline & Consumption & $\mathrm{C}$ & Consumption & \\
\hline
\end{tabular}
condition, social opportunity, and psychological condition (Table 1).

Table 1. Indices for evaluating worker household welfare. 
Table 1. Cont.

\begin{tabular}{|c|c|c|c|c|}
\hline $\begin{array}{c}\text { Dimensions of } \\
\text { Welfare Function }\end{array}$ & Index & $\begin{array}{l}\text { Type of } \\
\text { Variable }\end{array}$ & $\begin{array}{c}\text { Index Assignment and } \\
\text { Meaning }\end{array}$ & Literature \\
\hline \multirow{3}{*}{ Social security } & \multirow{3}{*}{$\begin{array}{l}\text { Engel's coefficient } \\
\text { Medical } \\
\text { insurance } \\
\text { Endowment } \\
\text { insurance }\end{array}$} & $\mathrm{C}$ & Engel's coefficient & \multirow{3}{*}{$\begin{array}{l}\text { Protective security is a social safety net that } \\
\text { provides support to people [22]. Engel's } \\
\text { coefficient is the proportion of food expenditure } \\
\text { to total household expenditure, which can } \\
\text { measure a family's ability to resist risk [38]. }\end{array}$} \\
\hline & & $\mathrm{D}$ & Yes $=1 ;$ No $=0$ & \\
\hline & & $\mathrm{D}$ & $\mathrm{Yes}=1 ; \mathrm{No}=0$ & \\
\hline \multirow{4}{*}{$\begin{array}{l}\text { Dwelling } \\
\text { condition }\end{array}$} & \multirow{4}{*}{$\begin{array}{l}\text { Live in apartment } \\
\text { or bungalow } \\
\text { Building } \\
\text { materials } \\
\text { Per capita } \\
\text { housing area } \\
\text { Environmental } \\
\text { pollution }\end{array}$} & $\mathrm{D}$ & $\begin{array}{l}\text { Apartment }=1 \\
\text { Bungalow }=0\end{array}$ & \multirow{4}{*}{$\begin{array}{l}\text { Dwelling condition is a basic function to protect } \\
\text { people through the quality of housing and } \\
\text { measuring the surrounding environment }[20,25] \text {. }\end{array}$} \\
\hline & & $\mathrm{D}$ & $\begin{array}{l}\text { Reinforced concrete }=1 \\
\text { Brick }=0\end{array}$ & \\
\hline & & $\mathrm{C}$ & Per capita housing area & \\
\hline & & $\mathrm{D}$ & No $=1 ;$ Yes $=0$ & \\
\hline \multirow{3}{*}{$\begin{array}{l}\text { Social } \\
\text { opportunity }\end{array}$} & Educational level & $\mathrm{C}$ & $\begin{array}{l}\text { School years completed } \\
\text { Very bad }=1 ; \text { Poor }=2\end{array}$ & \multirow{3}{*}{$\begin{array}{l}\text { The better the education, health, and training, } \\
\text { the more social opportunities people will have } \\
\text { [31]. Health status is judged by interviewees } \\
\text { themselves. }\end{array}$} \\
\hline & Health status & Q & $\begin{array}{l}\text { Neutral }=3 ; \text { Good }=4 ; \\
\text { Very good }=5\end{array}$ & \\
\hline & $\begin{array}{l}\text { Vocational } \\
\text { training }\end{array}$ & $\mathrm{D}$ & Yes $=1 ;$ No $=0$ & \\
\hline \multirow[t]{3}{*}{$\begin{array}{l}\text { Psychological } \\
\text { condition }\end{array}$} & Life satisfaction & Q & $\begin{array}{l}\text { Very unsatisfied }=1 ; \\
\text { Unsatisfied }=2 ; \\
\text { Neutral }=3 ; \text { Basically } \\
\text { satisfied }=4 ; \text { Very } \\
\text { satisfied }=5 \\
\text { Verv unsatisfied }=1 .\end{array}$ & \multirow[t]{3}{*}{$\begin{array}{l}\text { Psychological condition is an essential aspect of } \\
\text { welfare that affects people's feelings about their } \\
\text { lives. We used a typical five-level Likert scale to } \\
\text { understand respondents' responses }[20,39] \text {. }\end{array}$} \\
\hline & $\begin{array}{l}\text { Confidence in } \\
\text { future life }\end{array}$ & Q & $\begin{array}{l}\text { Unsatisfied }=2 ; \\
\text { Neutral }=3 ; \text { Basically } \\
\text { satisfied }=4 ; \text { Very } \\
\text { satisfied }=5\end{array}$ & \\
\hline & $\begin{array}{l}\text { Satisfaction of } \\
\text { CCLB policy }\end{array}$ & Q & $\begin{array}{l}\text { Very unsatisfied }=1 ; \\
\text { Unsatisfied }=2 ; \\
\text { Neutral }=3 ; \text { Basically } \\
\text { satisfied }=4 ; \text { Very } \\
\text { satisfied }=5\end{array}$ & \\
\hline
\end{tabular}

$\mathrm{D}$, dichotomous variable; $\mathrm{Q}$, virtual qualitative variable; $\mathrm{C}$, continuous variable.

\subsubsection{Data Sources}

The research data are drawn from the Key State-owned Forest Area Livelihood Monitoring project in 2012 and 2017, conducted in July and August by undergraduate and graduate students of Northeast Forestry University in the state-owned forest area of Heilongjiang, Inner Mongolia, and Jilin Province. We used face-to-face interviews with worker households. In 2012, the State Forestry Administration randomly selected 12 forestry bureaus, and each forestry bureau randomly selected 50-80 samples, a total of 706 questionnaires and 591 valid questionnaires. In 2017, from 12 forestry bureaus increase to 34 forestry bureaus, each forestry bureau randomly selected 30-50 samples, a total of 1050 questionnaires and 866 valid questionnaires. Each respondent was an adult family member representing the household or the household head. In the second survey, more of the respondents are the same households interviewed in 2012 (Table 2). 
Table 2. Basic characteristics of survey sample.

\begin{tabular}{|c|c|c|c|c|c|}
\hline & \multirow{2}{*}{ Categories } & \multicolumn{2}{|c|}{2012} & \multicolumn{2}{|c|}{2017} \\
\hline & & Number & Proportion (\%) & Number & Proportion $(\%)$ \\
\hline \multirow[t]{4}{*}{ Forestry enterprises } & Longjiang & 220 & 37.23 & 400 & 46.19 \\
\hline & Daxinganling & 88 & 14.89 & 142 & 16.40 \\
\hline & $\begin{array}{l}\text { Inner Mongolia } \\
\text { Daxinganling }\end{array}$ & 138 & 23.35 & 180 & 20.79 \\
\hline & Jilin & 145 & 24.53 & 144 & 16.63 \\
\hline \multirow[t]{2}{*}{ Gender of household head } & Male & 535 & 90.52 & 783 & 90.42 \\
\hline & Female & 56 & 9.48 & 83 & 9.58 \\
\hline \multirow{2}{*}{$\begin{array}{l}\text { Marital status of } \\
\text { household head }\end{array}$} & Unmarried & 571 & 96.62 & 783 & 90.42 \\
\hline & Married & 20 & 3.38 & 83 & 9.58 \\
\hline \multirow{5}{*}{$\begin{array}{l}\text { Age of household } \\
\text { head (years) }\end{array}$} & $\leq 30$ & 30 & 5.08 & 52 & 6.00 \\
\hline & $31-40$ & 96 & 16.24 & 144 & 16.63 \\
\hline & $41-50$ & 301 & 50.93 & 415 & 47.92 \\
\hline & $51-60$ & 101 & 17.09 & 227 & 26.21 \\
\hline & $>61$ & 63 & 10.66 & 28 & 3.23 \\
\hline \multirow{4}{*}{$\begin{array}{l}\text { Educational level of } \\
\text { household head }\end{array}$} & Primary school & 30 & 5.08 & 27 & 3.12 \\
\hline & Junior middle school & 226 & 38.24 & 278 & 32.10 \\
\hline & High school & 200 & 33.84 & 306 & 35.33 \\
\hline & University or above & 135 & 22.84 & 255 & 29.45 \\
\hline \multirow[t]{2}{*}{ Household size } & $\leq 3$ & 498 & 84.26 & 768 & 88.68 \\
\hline & $>4$ & 93 & 15.74 & 98 & 11.32 \\
\hline
\end{tabular}

\section{Results and Discussion}

\subsection{Changes in Welfare Functions of Worker Households}

\subsubsection{Welfare Functions of Worker Households}

The CCLB is an ecosystem project with a wide range, long operation period, and high employee participation. Employees in state-owned forest areas will inevitably be affected by the logging ban. According to our survey in the field and literature review, we found that the main manifestations are a lack of raw materials for the development of forestry industry enterprises, increased timber prices, and the impact on the economic income of employees [11,40]; people are more dependent on social security due to the transformation of enterprises and employment pressure [41]; with the need for ecological restoration, ecological relocation has been carried out, and living conditions have been improved [42]; and education, health, and psychological status are also important indicators to measure the level of welfare [43].

The total welfare of the state-owned forest areas changed a bit, from 0.381 to 0.380 (Table 3). Although there are some differences between the respondents in the two years, they all live in the same area and have similar living environment and source of livelihood. It can reflect the overall situation of state-owned forest areas. Total worker households welfare was still low and changed little during the period 2012-2017. However, there were substantial changes in terms of welfare function. Dwelling and psychological conditions improved by 9.5 and $14.8 \%$. Social opportunities and economic status declined by 27.1 and $9.1 \%$. At the same time, social security almost did not change at all. This shows that the infrastructure and mental state improved substantially during the five year period when the logging ban started. Due to the logging ban, some forest industry employees moved from forest areas to urban areas. At the same time, corresponding infrastructure was added, such as water supply, electricity, gas, heating, communication, and cable television. During the 2017 interviews, most employees expressed satisfaction with their lives. However, their economic status and opportunities declined significantly. This was mainly because the income of workers' families was adversely affected, especially from the collection of NTFPs. 
Social opportunities significantly reduced health status and training opportunities were reduced the most. In terms of the weight of importance, economic status is 0.485 , which plays an important role, followed by dwelling conditions (0.275) and social opportunity (0.124). Sources of expanded income, improved living conditions, and increased training opportunities will significantly improve the welfare of worker households.

Table 3. Changes in welfare functions before and after logging ban.

\begin{tabular}{|c|c|c|c|c|c|c|c|}
\hline \multirow{2}{*}{$\begin{array}{l}\text { Dimensions of } \\
\text { Function }\end{array}$} & \multicolumn{2}{|c|}{2012} & \multicolumn{2}{|c|}{2017} & \multirow{2}{*}{ Change } & \multirow{2}{*}{ Weight } & \multirow{2}{*}{$\begin{array}{c}\text { Mean } \\
\text { Difference }\end{array}$} \\
\hline & Membership & $\begin{array}{l}\text { Standard } \\
\text { Deviation }\end{array}$ & Membership & $\begin{array}{l}\text { Standard } \\
\text { Deviation }\end{array}$ & & & \\
\hline Economic status & 0.143 & & 0.130 & & $-9.1 \%$ & 0.485 & \\
\hline Wage income & 0.444 & 0.292 & 0.512 & 0.239 & $15.3 \%$ & 0.068 & $0.068 *$ \\
\hline NTFP business income & 0.144 & 0.622 & 0.055 & 0.169 & $-61.8 \%$ & 0.296 & $0.089 * * *$ \\
\hline Property income & 0.036 & 0.126 & 0.064 & 0.160 & $77.8 \%$ & 0.280 & $0.029 * * *$ \\
\hline Expanded income & 0.123 & 0.205 & 0.116 & 0.190 & $-5.7 \%$ & 0.220 & $0.008^{* * *}$ \\
\hline Consumption & 0.242 & 0.183 & 0.261 & 0.300 & $7.9 \%$ & 0.137 & $0.019^{* * *}$ \\
\hline Social security & 0.678 & & 0.679 & & $0.2 \%$ & 0.035 & \\
\hline Engel's coefficient & 0.596 & 0.236 & 0.595 & 0.208 & $-0.2 \%$ & 0.737 & $0.001 *$ \\
\hline Medical insurance & 0.906 & 0.292 & 0.909 & 0.287 & $0.3 \%$ & 0.135 & $0.003 * *$ \\
\hline Endowment insurance & 0.906 & 0.292 & 0.914 & 0.280 & $0.9 \%$ & 0.128 & $0.008^{* * *}$ \\
\hline Dwelling condition & 0.657 & & 0.719 & & $9.5 \%$ & 0.275 & \\
\hline $\begin{array}{c}\text { Live in apartment or } \\
\text { bungalow }\end{array}$ & 0.551 & 0.498 & 0.739 & 0.439 & $34.1 \%$ & 0.054 & $0.188^{* * *}$ \\
\hline Building materials & 0.651 & 0.263 & 0.75 & 0.499 & $15.2 \%$ & 0.137 & $0.186^{* * *}$ \\
\hline Per capita housing area & 0.267 & 0.177 & 0.227 & 0.172 & $-15.0 \%$ & 0.266 & $0.040 * * *$ \\
\hline Environmental pollution & 0.86 & 0.347 & 0.951 & 0.215 & $10.6 \%$ & 0.542 & $0.812^{* * *}$ \\
\hline Social opportunity & 0.539 & & 0.393 & & $-27.1 \%$ & 0.124 & \\
\hline Educational level & 0.534 & 0.194 & 0.557 & 0.182 & $4.3 \%$ & 0.233 & 0.022 \\
\hline Health status & 0.756 & 0.329 & 0.582 & 0.225 & $-23.0 \%$ & 0.215 & $0.174^{* * *}$ \\
\hline Vocational training & 0.457 & 0.499 & 0.251 & 0.434 & $-45.1 \%$ & 0.551 & $0.206^{* * *}$ \\
\hline $\begin{array}{l}\text { Psychological } \\
\text { condition }\end{array}$ & 0.500 & & 0.574 & & $14.8 \%$ & 0.080 & \\
\hline Life satisfaction & 0.500 & & 0.515 & 0.245 & $3.0 \%$ & 0.409 & \\
\hline Confidence in future life & 0.500 & & 0.660 & 0.250 & $32.0 \%$ & 0.256 & \\
\hline $\begin{array}{l}\text { Satisfaction of CCLB } \\
\text { policy }\end{array}$ & 0.500 & & 0.58 & 0.221 & $16.0 \%$ & 0.335 & \\
\hline Total welfare & 0.381 & & 0.380 & & $-0.3 \%$ & & \\
\hline
\end{tabular}

${ }^{*} p<0.1 .{ }^{* *} p<0.05 .{ }^{* * *} p<0.01$.

Economic status is the lowest among welfare functions. Among the indices of economic status, wage income was at the highest level, while variations among the households was reduced. As the workers' wages rose throughout the period, the gap between high and low earners was reduced. It is worth noting that NTFP business income dropped sharply by $61.8 \%$, indicating that the logging ban had a greater impact on these businesses. At present, NTFPs of state-owned forest areas mainly include wood-ear fungi and medicinal herbs. After CCLB, the production cost increased. Some people who relied on NTFPs as their main source of income may have turned to other ways of making a living. Those who did not rely on NTFPs as their main source of income reduced their activity of NTFP production. Although some scholars have also demonstrated that NTFPs play an important role in promoting the economic transformation of forest areas [14,44-46], that may not apply in this region as the contribution of NTFPs to household income decreased over the period. Due to the implementation of a more stringent forest protection policy, the use of forest land was also greatly restricted. As a result, the scale of NTFP business was reduced. Reduced NTFP income led to a reduction in family income, and in turn to a decline in the welfare of people dependent on the forest. 
Social security was maintained at a high level and was at its highest level among the five functional items of welfare. The social security function slightly increased over the period studied. This result is in line with reality, because the research object is mainly workers of state-owned forest areas employed by state-owned forestry enterprises, who are generally provided with basic social welfare programs such as medical and pension insurance. So, the social security situation is relatively stable. It is further explained that good social security has a positive effect on improving the welfare level of worker households.

Dwelling conditions were also maintained at a high level. Dwelling conditions improved by $9.5 \%$ during the five year period. With the implementation of measures such as renovating shantytowns and relocating remote mountainous areas, the living environment of employees was substantially improved. In the survey interviews, some workers said that when they lived in remote mountainous areas, transportation was very inconvenient, water and power supply were relatively difficult, and the sanitary conditions were poor. The worker households began to enjoy nicer, more comfortable housing. The increased value of the dwelling index reveals that the dwelling condition value improved thanks to the CCLB policy.

Social opportunities such as health welfare programs and job training opportunities decreased, but there was not much change in education level. Health status decreased by $23 \%$, which indicates that people aged, and their health declined, and the elderly population increased. Young people are not willing to return to work in forest areas [47]. It was also confirmed from the side of state-owned forest areas that economic development has been slowing down. The scenario to be faced will be "has a follow-up forest, but no successor". Vocational training fell by $45.1 \%$. The government should strengthen vocational training for workers [12]. In the past, vocational training was more focused on the training of work content. In the future, it should strengthen the training of personal skills to improve the quality of employees themselves and their employability.

Psychological condition ranked in the middle among welfare functions. The index value of psychological condition improved by $14.8 \%$ for the studied period. As the change in psychological condition was caused by the instantaneous change in the logging ban rather than a condition difference, we argue that psychological conditions in 2012 were considered as fuzzy, and the level is assumed to be in the middle (0.5). Although, the deterioration of economic status and health status, people are still full of confidence in the future. It shows that a positive attitude is conducive to the improvement of overall welfare. In the interviews, when we asked respondents about their views on CCLB, most of them expressed strong support for the logging ban. They said that the forest should be protected and restored. One employee said, "I grew up in this mountain. The forest is my friend. When I was logging, I feel very sad to see the trees being cut down, but I have no choice, it is my work." When did we asked whether they were worried about the future, the employee said, "I'm not very worried, because it's a state-owned enterprise and I'm old enough to get a pension after retirement". People have deep feelings for forests and also have confidence in state-owned enterprises. While the government provides subsidies, enterprises are also actively looking for alternative industries $[5,48]$.

\subsubsection{Welfare Function Based on Livelihood Strategies}

When the government formulates forest policies, the livelihood of people who depend on forests and the conservation of natural forests need to be taken into account together $[41,49]$. Since CCLB, the government has aimed to reforest and conserve the forest. In the course of forest policy change, forest dwellers have been seeking new ways to improve their livelihoods. Workers began to look for other ways to make a living and to reduce their dependence on forestry [13].

The proportions of groups among the households surveyed are shown in Figure 2. Table 4 shows the change in the welfare function of livelihood strategies before and after the logging ban. 

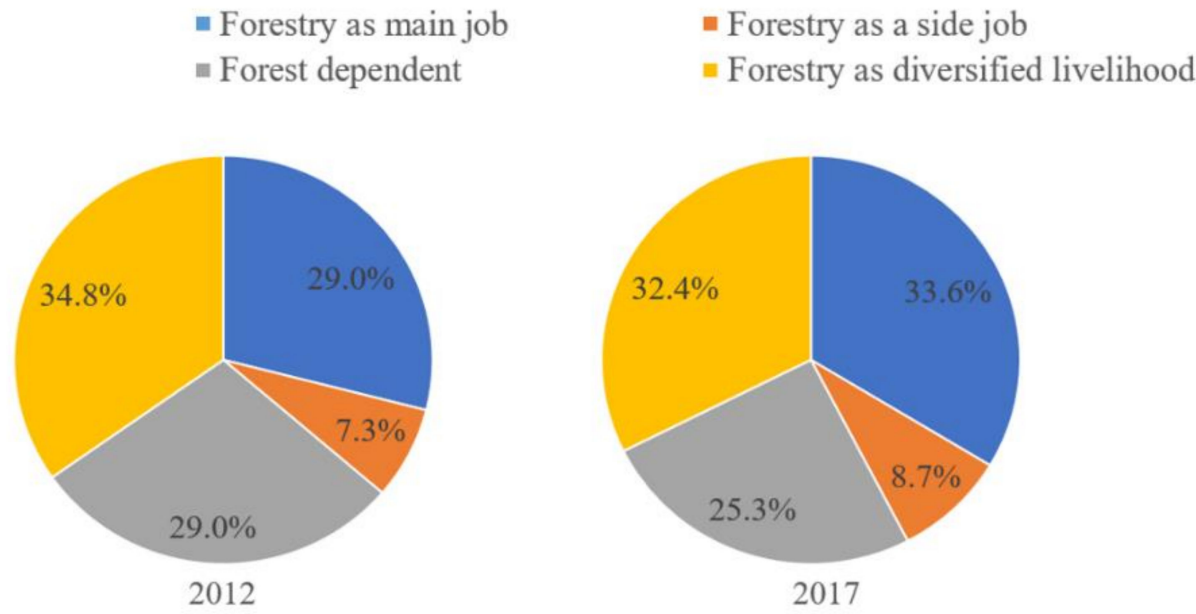

Figure 2. Change in livelihood strategies of worker households.

Table 4. Change in welfare functions of livelihood types before and after logging ban.

\begin{tabular}{|c|c|c|c|c|c|c|c|c|}
\hline \multirow[t]{2}{*}{ Dimensions of Function } & \multicolumn{2}{|c|}{$\begin{array}{c}\text { Forestry as Main } \\
\text { Job }\end{array}$} & \multicolumn{2}{|c|}{$\begin{array}{l}\text { Forestry as Side } \\
\text { Job }\end{array}$} & \multicolumn{2}{|c|}{ Forest Dependent } & \multicolumn{2}{|c|}{$\begin{array}{c}\text { Forestry as Diversified } \\
\text { Livelihood }\end{array}$} \\
\hline & 2012 & 2017 & 2012 & 2017 & 2012 & 2017 & 2012 & 2017 \\
\hline Economic status & 0.089 & 0.091 & 0.197 & 0.246 & 0.122 & 0.119 & 0.194 & 0.149 \\
\hline Wage income & 0.349 & 0.374 & 0.496 & 0.315 & 0.651 & 0.662 & 0.340 & 0.592 \\
\hline NTFP business income & 0.045 & 0.028 & 0.102 & 0.132 & 0.052 & 0.027 & 0.312 & 0.084 \\
\hline Property income & 0.028 & 0.059 & 0.103 & 0.338 & 0.040 & 0.024 & 0.025 & 0.028 \\
\hline Expanded income & 0.048 & 0.038 & 0.250 & 0.256 & 0.067 & 0.052 & 0.207 & 0.209 \\
\hline Consumption & 0.248 & 0.239 & 0.362 & 0.257 & 0.263 & 0.346 & 0.193 & 0.218 \\
\hline Social security & 0.677 & 0.752 & 0.688 & 0.699 & 0.721 & 0.554 & 0.640 & 0.694 \\
\hline Engel's coefficient & 0.579 & 0.673 & 0.610 & 0.614 & 0.645 & 0.427 & 0.568 & 0.643 \\
\hline Medical insurance & 0.953 & 0.972 & 0.907 & 0.933 & 0.935 & 0.908 & 0.843 & 0.839 \\
\hline Endowment insurance & 0.953 & 0.976 & 0.907 & 0.947 & 0.935 & 0.917 & 0.843 & 0.839 \\
\hline Dwelling condition & 0.684 & 0.730 & 0.678 & 0.680 & 0.653 & 0.648 & 0.633 & 0.655 \\
\hline Live in apartment or bungalow & 0.615 & 0.972 & 0.535 & 0.653 & 0.529 & 0.642 & 0.520 & 0.595 \\
\hline Building materials & 0.641 & 0.545 & 0.674 & 0.533 & 0.650 & 0.440 & 0.654 & 0.384 \\
\hline Per capita housing area & 0.266 & 0.323 & 0.290 & 0.216 & 0.285 & 0.114 & 0.248 & 0.219 \\
\hline Environmental pollution & 0.906 & 0.952 & 0.884 & 0.947 & 0.847 & 0.963 & 0.828 & 0.943 \\
\hline Social opportunity & 0.591 & 0.432 & 0.598 & 0.364 & 0.555 & 0.385 & 0.471 & 0.368 \\
\hline Educational level & 0.549 & 0.522 & 0.570 & 0.414 & 0.567 & 0.626 & 0.487 & 0.576 \\
\hline Health status & 0.837 & 0.635 & 0.791 & 0.627 & 0.712 & 0.545 & 0.718 & 0.545 \\
\hline Vocational training & 0.512 & 0.314 & 0.535 & 0.240 & 0.488 & 0.220 & 0.368 & 0.211 \\
\hline Psychological conditions & 0.500 & 0.602 & 0.500 & 0.620 & 0.500 & 0.542 & 0.500 & 0.557 \\
\hline Life satisfaction & 0.500 & 0.557 & 0.500 & 0.583 & 0.500 & 0.462 & 0.500 & 0.493 \\
\hline Confidence in future life & 0.500 & 0.695 & 0.500 & 0.730 & 0.500 & 0.631 & 0.500 & 0.628 \\
\hline Satisfaction with CCLB policy & 0.500 & 0.586 & 0.500 & 0.580 & 0.500 & 0.572 & 0.500 & 0.581 \\
\hline Total welfare & 0.369 & 0.373 & 0.421 & 0.426 & 0.373 & 0.347 & 0.390 & 0.367 \\
\hline
\end{tabular}

On the whole, households practicing forestry as a side job had the best welfare, followed by those practicing forestry as diversified livelihood or main job, while those dependent solely on forestry had the worst in 2017. This means that the logging ban had the greatest impact on households practicing forestry as their main job and those dependent solely on forestry. This also indicates that workers and families should enrich their livelihood structure and not rely on only forestry for a living, as it can be easily affected by forest policy.

Households practicing forestry as their main job had low welfare levels in both 2012 and 2017, but compared with those with other livelihood strategies, their welfare level was more stable even though it was low. This shows that relying on only forestry for 
their livelihoods could not improve their welfare. Their property income and expanded income are low. Therefore, it is necessary to expand income sources and restructure the livelihood strategies. Further analysis shows that social security and dwelling conditions of households practicing forestry as their main job were significantly higher compared to other types of worker families, but their economic status was lower than that of other families. The welfare of households practicing forestry as a side job was at a medium level among the four groups. Their welfare was better in 2017 than in 2012. Their welfare was the highest among all groups in both years surveyed. This indicates that the logging ban in 2014-2015 had little effect on the welfare of households practicing forestry as a side job. Their economic status was significantly higher than other livelihood groups. NTFP business income of this group was twice as high as that of other livelihood types, and their property income was also about twice as high. This may be because their operation of NTFP businesses maintained a certain scale with fixed supply and sales channels. So, the logging ban had little impact on their operations and their engagement in NTFP business made a great contribution to improving their welfare.

The forest dependent group had a low welfare level. It even declined from 2012 to 2017 by $7.0 \%$. The logging ban in 2014-2015 hit households dependent on forest resources very hard, and this group suffered seriously from the forest policy change. Especially, their Engel's coefficient in 2017 decreased by 33.8\% compared to 2012, while that of other households showed an upward trend. During the interviews, some residents said that moving from the forest to urban areas made their life much more convenient, but the cost of living also increased substantially. They said when they lived in the mountains where the forest farm was located, they could grow some crops by themselves, but in order to restore the forest ecosystem, they were relocated. The fact that the consumption of the forest dependent group increased by $31.6 \%$ proves this point.

The group practicing forestry as part of a diversified livelihood also had low level of welfare. Among their welfare functions, their economic status declined the most, with a $23.0 \%$ decrease over the five year period. Their NTFP business income decreased by $73.3 \%$ over the same period. Before the logging ban, worker households could make use of waste residues from forestry operations for their own NTFP businesses. As the supply of raw materials from forests became limited after the ban, NTFP businesses became difficult. At the same time, work activities and work hours were also adjusted. For example, during harvesting, the production period was mainly concentrated in the winter. After the logging ban, the activities for forest protection were concentrated in the spring, summer, and autumn. The workers' time to engage in NTFP businesses was limited and the development of these businesses was constrained.

\subsection{Changes in Welfare Gap of Worker Households}

\subsubsection{Welfare Gap of Worker Households}

We attempted to study the internal structure of family welfare distribution among the groups of households according to the method described above to calculate the welfare gap, and the results are shown in Table 5. First, the welfare gap shows a slight downward trend of $6.4 \%$ over the period. It shows that the overall welfare gap narrowed after logging ban. Second, the gap between the groups became larger, and the within-group gap became smaller. Third, it is important to note that the within-group gap contributed the most to the overall welfare gap. Before and after the logging ban, the within-group contribution was more than $93 \%$ of the overall welfare gap. This is a significant point that indicates that although the welfare gap was narrowed, the within-group gap between rich and poor is very large. The welfare effect of logging ban appears to be fair; however, the within-group gap is still an important issue worthy of attention. To further explore the reasons, according to the value of welfare function we divided worker households into three categories: low welfare $(0.000-0.400)$, medium welfare $(0.401-0.600)$, and high welfare $(0.601-1.000)$. 
Table 5. Theil index calculation results.

\begin{tabular}{cccccc}
\hline \multirow{2}{*}{ Year } & \multirow{2}{*}{ Welfare Gap } & Between-Group Gap & Within-Group Gap & \multicolumn{2}{c}{ Contribution Rate (\%) } \\
\cline { 3 - 6 } & & & & Between-Group & Within-Group \\
\hline 2012 & 0.0219 & 0.0006 & 0.0213 & 2.7397 & 97.2603 \\
2017 & 0.0205 & 0.0013 & 0.0192 & 6.3415 & 93.6585 \\
\hline
\end{tabular}

The specific distribution is shown in Table 6. On the whole, most of the worker households had medium welfare, followed by those with low welfare. The low welfare households increased from $14.0 \%$ in 2012 to in $27.8 \%$ in 2017, medium welfare households decreased from 73.5 to $70.0 \%$, and high-welfare households dropped from 12.5 to $2.2 \%$. This shows that the narrowing of the welfare gap was not due to an improvement in the overall welfare level, but to the increase in low welfare and the decrease in high welfare. Therefore, in the process of improving the welfare of worker households, we should pay more attention to improving those with a low welfare level and maintaining those with a high welfare level, and know their problems in production and life in a timely manner.

Table 6. Internal distribution of welfare.

\begin{tabular}{|c|c|c|c|c|c|c|c|c|c|c|}
\hline \multirow[t]{2}{*}{ Level } & \multicolumn{2}{|c|}{ Total } & \multicolumn{2}{|c|}{ Forestry as Main Job } & \multicolumn{2}{|c|}{ Forestry as Side Job } & \multicolumn{2}{|c|}{ Forest Dependent } & \multicolumn{2}{|c|}{$\begin{array}{l}\text { Forestry as } \\
\text { Diversified } \\
\text { Livelihood }\end{array}$} \\
\hline & 2012 & 2017 & 2012 & 2017 & 2012 & 2017 & 2012 & 2017 & 2012 & 2017 \\
\hline $0.000-0.400$ & $14.0 \%$ & $27.8 \%$ & $10.5 \%$ & $13.7 \%$ & $8.9 \%$ & $23.7 \%$ & $7.0 \%$ & $38.8 \%$ & $23.9 \%$ & $35.0 \%$ \\
\hline $0.401-0.600$ & $73.5 \%$ & $70.0 \%$ & $82.5 \%$ & $83.2 \%$ & $68.9 \%$ & $68.4 \%$ & $76.6 \%$ & $59.8 \%$ & $64.4 \%$ & $64.6 \%$ \\
\hline $0.601-1.000$ & $12.5 \%$ & $2.2 \%$ & $7.0 \%$ & $3.1 \%$ & $22.2 \%$ & $7.9 \%$ & $16.4 \%$ & $1.4 \%$ & $11.7 \%$ & $0.4 \%$ \\
\hline
\end{tabular}

\subsubsection{Welfare Gap Based on Livelihood Strategies}

To better analyze the welfare gap within each group, we calculated it based on different livelihood strategies (Figure 3). In general, the welfare gap of households practicing forestry as part of a diversified livelihood was the largest, followed by those solely dependent on forests and practicing forestry as a side job, and it was smallest for those practicing forestry as their main job. From the perspective of change trends, the welfare gap for those practicing forestry as their main job was stable, for those practicing forestry as a side job and those solely dependent on forests was on the rise, and for those practicing forestry as part of a diversified livelihood showed a downward trend.

The reasons are as follows: The group for whom forestry is their main job is mainly composed of employees of state-owned forestry enterprises. Their income, social security, and dwelling benefits are stable. For the group for whom forestry is a side job, in response to the CCLB, they actively engaged in other activities to secure complementary income. The forest-dependent group has low income in general due to their great dependence on forestry, and some worker households have gradually fallen behind the others. The group for whom forestry is part of a diversified livelihood rely on NTFP business for most of their income. As the logging ban restricted the supply of raw materials, the development of NTFP businesses became difficult. 


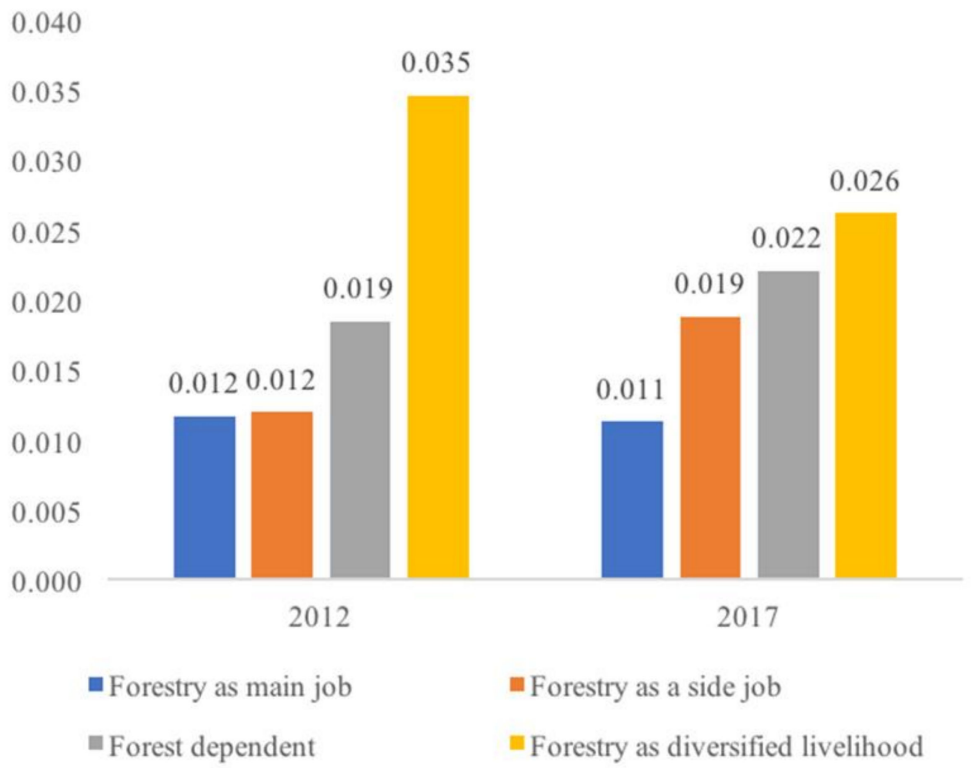

Figure 3. Theil index of livelihood types.

\section{Conclusions}

Since 2014-2015, when the state-owned forest areas of northeast China were subjected to a logging ban, that area has undergone systematic and continuous social reforms. Such policy and associated social changes ultimately affect the welfare of people who live in the area. Therefore, we studied the welfare change in forestry worker households with a focus on their welfare capacity, applying Sen's function and capability welfare theory. We evaluated the effect of the logging ban in terms of changes in welfare functions and the welfare gap in different groups of households.

Our study shows that the welfare of forest worker households in northeastern China stayed at a low level and largely did not change for the period 2012-2017 after a policy banning logging in state-owned forests was implemented. The logging ban impacted worker households differently based on their livelihood strategies. This shows that the logging ban had a large impact on people solely dependent on forests $(0.426-0.373)$ and people practicing forestry as part of a diversified livelihood (0.390-0.367). The impact of the logging ban on people for whom forestry is their main job and those for whom forestry is a side job was minimal, even though their welfare level was still relatively low. The social security, dwelling conditions, and psychological conditions of forestry workers improved, while their economic status and social opportunities shrunk slightly. In terms of the weight of impact on welfare change, the order of importance was economic status, dwelling conditions, and social opportunity. This indicates that these three factors have a great influence on the total welfare of worker households. So, in to order to reduce the impact of the forest conservation policy on people's welfare, the government should pay attention to their economic status, dwelling conditions, and social opportunity.

The welfare gap of forest worker households in northeastern China has narrowed a bit. It seems that the welfare distribution has become fairer than before. However, the number of low welfare families increased, while the number of high welfare families decreased. This shows that the reason for the narrowing of the welfare gap is that overall welfare became worse, rather than increased. The government should be concerned about this issue of welfare change and gaps among people affected by the forest conservation policy. It is also important because not only did the between-group gap become bigger, but also within-group disparities still contribute the most to the worker households' welfare gap, at more than $93 \%$. Along with the narrowing of the welfare gap of households practicing forestry as part of a diversified livelihood, the welfare gap of other groups increased by varying degrees. 
Based on our research findings, we suggest that forest conservation policies such as CCLB be complemented with livelihood supporting programs that can facilitate: (1) income sources to help in securing raw materials for NTFP business, and cooperative organizations of workers' businesses; (2) provision of non-economic welfare, such as improving the living environment and constructing community green spaces; (3) construction of medical and healthcare institutions, especially for aging rural populations; (4) targeted vocational education and training for professional capacity building and employability; and (5) targeted assistance according to different livelihood strategies.

Author Contributions: Y.G. and S.S. conceived and designed the study; Y.G. and Y.Y.-C. supervised the study. Y.G. organized the survey, and funding acquisition; S.S. collected and analyzed the data, interpreted the results and wrote the first manuscript; S.S. and Y.Y.-C. reviewed and edited the draft manuscript. All authors have read and agreed to the published version of the manuscript.

Funding: This research was funded by the China Scholarship Council.

Acknowledgments: This work was supported by the China Scholarship Council and the Key Stateowned Forest Area Livelihood Monitoring project of China.

Conflicts of Interest: The authors declare no conflict of interest.

\section{References}

1. Heinonen, T.; Pukkala, T.; Mehtätalo, L.; Asikainen, A.; Kangas, J.; Peltola, H. Scenario analyses for the effects of harvesting intensity on development of forest resources, timber supply, carbon balance and biodiversity of Finnish forestry. For. Policy Econ. 2017, 80, 80-98. [CrossRef]

2. Liu, K.; Liang, Y.; He, H.S.; Wang, W.J.; Huang, C.; Zong, S.; Wang, L.; Xiao, J.; Du, H. Long-Term Impacts of China's New Commercial Harvest Exclusion Policy on Ecosystem Services and Biodiversity in the Temperate Forests of Northeast China. Sustainability 2018, 10, 1071. [CrossRef]

3. Soe, K.T.; Yeo-Chang, Y. Livelihood Dependency on Non-Timber Forest Products: Implications for REDD+. Forests 2019, 10, 427. [CrossRef]

4. Hein, L.; van der Meer, P.J. REDD+ in the context of ecosystem management. Curr. Opin. Environ. Sustain. 2012, 4, 604-611. [CrossRef]

5. Sun, X.; Canby, K.; Liu, L. China's logging ban in natural forests: Impacts of extended policy at home and abroad. For. Trends Inf. Brief 2016, 1-8. Available online: https:/ / www.forest-trends.org/publications / china\%C2\%92s-logging-ban-in-natural-forests / (accessed on 14 March 2016).

6. Dai, L.; Zhao, F.; Shao, G.; Zhou, L.; Tang, L. China's classification-based forest management: Procedures, problems, and prospects. Environ. Manag. 2009, 43, 1162-1173. [CrossRef] [PubMed]

7. Yu, D.; Zhou, L.; Zhou, W.; Ding, H.; Wang, Q.; Wang, Y.; Wu, X.; Dai, L. Forest management in Northeast China: History, problems, and challenges. Environ. Manag. 2011, 48, 1122-1135. [CrossRef] [PubMed]

8. Zhang, P. China's forest policy for the 21st century. Science 2000, 288, 2135-2136. [CrossRef]

9. Wang, S.; Cornelis van Kooten, G.; Wilson, B. Mosaic of reform: Forest policy in post-1978 China. For. Policy Econ. 2004, 6, 71-83. [CrossRef]

10. Dai, L.; Li, S.; Zhou, W.; Qi, L.; Zhou, L.; Wei, Y.; Li, J.; Shao, G.; Yu, D. Opportunities and challenges for the protection and ecological functions promotion of natural forests in China. For. Ecol. Manag. 2018, 410, 187-192. [CrossRef]

11. Simorangkir, D.; Sardjono, M.A. Implications of forest utilization, conversion policy and tenure dynamics on resource management and poverty reduction. Underst. Tenure South Southeast Asia 2006, 14, 197.

12. Zhang, X.; Kang, L.; Huang, W. Study on the Vocational Adaptability of Re-Employment Workers in Northeast State-Owned Forest Region: Based on the Empirical Data of Yichun Forest Region. Issues For. Econ. 2017, 4, 2.

13. Zhu, H.; Hu, S. The Effect on Livelihood Styles Differentiation of Worker Households in Key National Forest Areas by Comprehensive "Stop Cutting" Policy. For. Econ. 2016, 4, 8-12.

14. Liu, S.; Xu, J. Livelihood mushroomed: Examining household level impacts of non-timber forest products (NTFPs) under new management regime in China's state forests. For. Policy Econ. 2019, 98, 44-53. [CrossRef]

15. SFA. The Eighth National Forest Resources Inventory; State Forestry Administration: Beijing, China, 2013.

16. Heffetz, O. Who sees what? Demographics and the visibility of consumer expenditures. J. Econ. Psychol. 2012, 33, 801-818. [CrossRef]

17. Fisher, A.C. Investment under uncertainty and option value in environmental economics. Resour. Energy Econ. 2000, 22, 197-204. [CrossRef]

18. Anand, P.; Hunter, G.; Smith, R. Capabilities and Well-Being: Evidence Based on the Sen-Nussbaum Approach to Welfare. Soc. Indic. Res. 2005, 74, 9-55. [CrossRef]

19. Bell, D.E. Multilinear representations for ordinal utility functions. J. Math. Psychol. 1987, 31, 44-59. [CrossRef] 
20. Li, H.; Huang, X.; Kwan, M.-P.; Bao, H.X.H.; Jefferson, S. Changes in farmers' welfare from land requisition in the process of rapid urbanization. Land Use Policy 2015, 42, 635-641. [CrossRef]

21. Sen, A. Capability and Well-Being. Qual. Life 1993, 30, 270-293.

22. Sen, A. Elements of a theory of human rights. Philos. Public Aff. 2004, 32, 315-356. [CrossRef]

23. Sen, A. Welfare theory. In Handworterbuch der Mathematischen Wirtschaftswissenschaften [Encyclopedic Handbook of Mathematical Economic Sciences]; Gabler: Wiesbaden, Germany, 1979.

24. Sen, A. Inequality Re-Examined Oxford; Clarendon Press: Oxford, UK, 1992.

25. Martinetti, E.C. A multidimensional assessment of well-being based on Sen's functioning approach. Rivista Internazionale di Scienze Sociali 2000, 108, 207-239.

26. Zhao, L.; Shi, J.; Kang, X.; Hong, H. Research on crop insurance and change in farmers' welfare: Evidence from China's Inner Mongolia. Int. Food Agribus. Manag. Rev. 2019, 22, 519-533. [CrossRef]

27. Huang, X.; Yi, L.; Ran, Y.; Zhao, X. Reconsidering the Controversial Land Use Policy of "Linking the Decrease in Rural Construction Land with the Increase in Urban Construction Land": A Local Government Perspective. China Rev. 2014, 14, 175-198.

28. Zadeh, L.A. Fuzzy sets as a basis for a theory of possibility. Fuzzy Sets Syst. 1978, 1, 3-28. [CrossRef]

29. Cerioli, A.; Zani, S. A Fuzzy Approach to the Measurement of Poverty; Springer Verlag: Berlin, Germany, 1990.

30. Cheli, B.; Lemmi, A. A'totally'fuzzy and relative approach to the multidimensional analysis of poverty. Econ. Notes 1995, 24, 115-134.

31. Ye, J.; Wang, Q. A Welfare Evaluation of the Rural to Urban Migrants: Based on Sen's Capability Approach. China Econ. Q. 2014, $4,1323-1344$.

32. Akita, T. Decomposing regional income inequality in China and Indonesia using two-stage nested Theil decomposition method. Ann. Reg. Sci. 2003, 37, 55-77. [CrossRef]

33. Conceição, P.; Galbraith, J.K.; Bradford, P. The Theil Index in Sequences of Nested and Hierarchic Grouping Structures: Implications for the Measurement of Inequality through Time, with Data Aggregated at Different Levels of Industrial Classification. East. Econ. J. 2001, 27, 491-514.

34. Kang, X.; Yang, D. An analysis on the difference of regional energy consumption in China based on the method of the Theil index. Resour. Sci. 2010, 3, 485-490.

35. Jie, L.I. On Rural Households' Forestry-related Livelihood Choice in the Mountainous Areas in West of China and Influencing Factors. China Popul. Resour. Environ. 2010, 8, 8-16.

36. Liu, W.; Li, J.; Ren, L.; Xu, J.; Li, C.; Li, S. Exploring Livelihood Resilience and its Impact on Livelihood Strategy in Rural China. Soc. Indic. Res. 2020, 150, 977-998. [CrossRef]

37. Kawanaka, T. Making Democratic Governance Work: How Regimes Shape Prosperity, Welfare, and Peace by Pippa Norris, New York: Cambridge University Press, 2012, xii+ 281 pp. Dev. Econ. 2014, 52, 88-90. [CrossRef]

38. Gao, J.; Qiao, R. Analysis on variation in farmers welfare after rural-urban land conversion. China Popul. Resour. Environ. 2011, 21, 99-105.

39. Bonnefon, J.-F. New ambitions for a new paradigm: Putting the psychology of reasoning at the service of humanity. Think. Reason. 2013, 19, 381-398. [CrossRef]

40. Tesfaye, Y.; Roos, A.; Campbell, B.M.; Bohlin, F. Livelihood strategies and the role of forest income in participatory-managed forests of Dodola area in the bale highlands, southern Ethiopia. For. Policy Econ. 2011, 13, 258-265. [CrossRef]

41. Sunderlin, W.D.; Angelsen, A.; Belcher, B.; Burgers, P.; Nasi, R.; Santoso, L.; Wunder, S. Livelihoods, forests, and conservation in developing countries: An Overview. World Dev. 2005, 33, 1383-1402. [CrossRef]

42. Liu, W.; Li, J.; Xu, J. Impact of the ecological resettlement program in southern Shaanxi Province, China on households' livelihood strategies. For. Policy Econ. 2020, 120, 102310. [CrossRef]

43. Garekae, H.; Lepetu, J.; Thakadu, O.T.; Sebina, V.; Tselaesele, N. Community perspective on state forest management regime and its implication on forest sustainability: A case study of Chobe Forest Reserve, Botswana. J. Sustain. For. 2020, 39, 1-18. [CrossRef]

44. Zhu, H.; Hu, S.; Ren, Y.; Ma, X.; Cao, Y. Determinants of engagement in non-timber forest products (NTFPs) business activities: A study on worker households in the forest areas of Daxinganling and Xiaoxinganling Mountains, northeastern China. For. Policy Econ. 2017, 80, 125-132. [CrossRef]

45. Illukpitiya, P.; Yanagida, J.F. Farming vs forests: Trade-off between agriculture and the extraction of non-timber forest products. Ecol. Econ. 2010, 69, 1952-1963. [CrossRef]

46. Mutenje, M.J.; Ortmann, G.F.; Ferrer, S.R. Management of non-timber forestry products extraction: Local institutions, ecological knowledge and market structure in South-Eastern Zimbabwe. Ecol. Econ. 2011, 70, 454-461. [CrossRef]

47. Geng, Y.; Wan, Z.; Wei, L.; Min, L. Study on Process and Policies of the Reform of Stated-owned Forest Regions-Based on the Investigations on Forestry Industrial Group of Longjiang and Forestry Group of Daxing'anling Region. For. Econ. $2017,2,3-11$.

48. Jiang, X.; Gong, P.; Bostedt, G.; Xu, J. Impacts of policy measures on the development of state-owned forests in northeast China: Theoretical results and empirical evidence. Environ. Dev. Econ. 2014, 19, 74-91. [CrossRef]

49. Soe, K.T.; Yeo-Chang, Y. Perceptions of forest-dependent communities toward participation in forest conservation: A case study in Bago Yoma, South-Central Myanmar. For. Policy Econ. 2019, 100, 129-141. [CrossRef] 